\title{
Tumor Susceptibility Gene 101 Mediates Anoikis Resistance of Metastatic Thyroid Cancer Cells
}

\author{
KITTIRAT SAHARAT ${ }^{1}$, KRIENGSAK LIRDPRAPAMONGKOL ${ }^{2}$, DARANEE CHOKCHAICHAMNANKIT ${ }^{2}$, \\ CHANTRAGAN SRISOMSAP ${ }^{2}$, JISNUSON SVASTI ${ }^{1,2}$ and N. MONIQUE PARICHARTTANAKUL ${ }^{2}$ \\ ${ }^{1}$ Applied Biological Sciences Program, Chulabhorn Graduate Institute, Chulabhorn Royal Academy, Bangkok, Thailand; \\ ${ }^{2}$ Laboratory of Biochemistry, Chulabhorn Research Institute, Bangkok, Thailand
}

\begin{abstract}
Background/Aim: Resistance to anoikis is a prerequisite step in metastasis, a major cause of death in patients with cancer, including thyroid cancer. Impairing anoikis resistance is a possible strategy for therapy of metastatic cancer. We, therefore, we aimed to investigate the key players of anoikis resistance. Materials and Methods: Papillary-type (BCPAP), follicular-type (FTC133), and anaplastic-type (ARO) thyroid carcinoma cells, cultured in poly(2-hydroxyethyl methacrylate)-coated plates to mimic circulating cells, were used as model systems in this study. Flow cytometry and softagar assays were used to determine cells exhibiting anoikis resistance. Proteomics was used to identify candidate proteins and validated using western blot and siRNA knockdown. Results: Only ARO cells showed both anoikis resistance potential and anchorage-independent growth ability. Tumor susceptibility gene 101 protein (TSG101) was identified to be potentially important in anoikis resistance, which was confirmed by an increase in anoikis and expression of a proapoptotic protein (BCL-2 like protein 4) and an apoptotic marker (cleaved poly-ADP ribose polymerase) in floating siTSG101-knockdown cells. Conclusion: To our knowledge, this is the first study that implicates the importance of TSG101 in anoikis resistance of thyroid cancer.
\end{abstract}

Metastasis is a multi-step process involving tissue invasion, cell migration, anoikis resistance and implantation to other organs. At the cellular level, metastasizing cells detach from the extracellular matrix (ECM) and neighboring cells in the primary organ and travel through the circulatory system.

This article is freely accessible online.

Correspondence to: Dr. N. Monique Paricharttanakul, Laboratory of Biochemistry, Chulabhorn Research Institute, 54 Kamphaeng Phet 6, Laksi, Bangkok 10210, Thailand. E-mail: nilubol@cri.or.th

Key Words: TSG101, anoikis resistance, metastasis, proteomics, thyroid cancer.
Translocation of normal epithelial cells is normally inhibited by a detachment-induced cell death mechanism called anoikis, which is a self-defense mechanism of multicellular organisms against cellular detachment, re-adhesion on inappropriate ECM or other organs, and dysplastic growth; in other words, anoikis is a natural barrier to metastasis $(1,2)$. Metastasizing cancer cells develop a survival mechanism called anoikis resistance that permits them to survive when they detach from the ECM, then float in the circulatory system, and grow in distant organs (3). Therefore, targeting anoikis resistance is a promising strategy for anti-metastasis therapy.

Thyroid cancer is ranked in the top ten female malignancies, with increasing worldwide incidence, as reported in $2016(4,5)$. Despite early diagnosis and available effective treatments, the mortality rate has been increasing by about $0.8 \%$ annually (6). Indeed, primary thyroid cancer is completely curable by available treatments whereas metastatic thyroid cancer is incurable, leading to death and significantly reducing the survival rate to approximately $50 \%$ within 5 years $(5,7)$. More than $90 \%$ of all thyroid cancer types are derived from thyroid epithelial cells or follicular cells that are clinically classified into three subtypes based on their pathology, namely papillary thyroid carcinoma (PTC), follicular thyroid carcinoma (FTC) and anaplastic thyroid carcinoma (ATC) (8). Clinical information indicates a metastatic potential in increasing order for PTC, FTC and ATC. Approximately $15-50 \%$ of PTCs invade neighboring tissues and metastasizes only to regional lymph nodes, about $20 \%$ of FTCs metastasize to distant organs including bone and lung, while ATC is the most aggressive type, with more than $98 \%$ of all cases metastasizing to bone, lung and brain $(8,9)$. The difference in their metastatic property makes thyroid cancer a good model for studying metastasis. However, few studies have reported on anoikis resistance in thyroid cancer, with some proteins showing potential involvement, such as S100A11, connexin 43 and myocardinrelated transcription factor A (10-12). Unfortunately, these proteins were implicated with the weakly metastatic subtype (PTC), rather than FTC or ATC. Even though proteomics is 
a valuable tool for identifying essential proteins involved in cellular mechanisms, there is currently no report of studies on anoikis resistance in thyroid cancer using proteomics.

In the present study, we aimed to identify important proteins involved in anoikis resistance of human thyroid cancer cells using proteomics, by comparing attached cells in monolayer culture with floating cells cultured under non-adherent condition that mimic metastasizing cells in circulation.

\section{Materials and Methods}

Cell culture. Human PTC cell line (BCPAP), human FTC cell line (FTC133) and human ATC cell line (ARO) were provided by Professor Johan Lillehaug (University of Bergen, Bergen, Norway). BCPAP and ARO cells were maintained in RPMI and DMEM (Invitrogen, Carlsbad, CA, USA), respectively, supplemented with $10 \% \mathrm{v} / \mathrm{v}$ fetal bovine serum (FBS; Millipore, Temecula, CA, USA) and $1 \% \mathrm{v} / \mathrm{v}$ antibiotic-antimycotic (Gibco, Carlsbad, CA, USA). FTC133 cells were maintained in 1:1 mixture of DMEM: F12 media (Invitrogen) supplemented with 10\% v/v FBS, 1\% v/v antibioticantimycotic, and $2 \mathrm{mM}$ L-glutamine (Invitrogen). All cells were maintained at $37^{\circ} \mathrm{C}$ in a humidified incubator with $5 \% \quad \mathrm{CO}_{2}$. Floating cells were obtained by culturing under non-adherent condition using plates pre-coated with $10 \mathrm{mg} / \mathrm{ml}$ poly $(2-$ hydroxyethyl methacrylate) (polyHEMA; Sigma-Aldrich, St. Louis, MO, USA) (13). Cell morphologies were observed under a phasecontrast inverted microscope (Eclipse TS100; Nikon, Tokyo, Japan).

Anoikis/Apoptosis cell death assay. Floating cells were harvested by centrifugation at $300 \times \mathrm{g}, 18^{\circ} \mathrm{C}$ for $5 \mathrm{~min}$. Attached cells were trypsinized, and then centrifuged at $300 \times g, 18^{\circ} \mathrm{C}$ for $5 \mathrm{~min}$. Media were replaced with fresh media containing $1 \% \mathrm{v} / \mathrm{v}$ FBS (without antibiotics). Muse Annexin V \& Dead Cell Assay Kit (Merck Millipore, Darmstadt, Germany) was used to determine the level of anoikis and apoptosis of floating and attached cells, respectively, following the manufacturer's instructions. In brief, Muse Annexin V \& Dead Cell Reagent that contains fluorescent dyes (annexin V and 7-aminoactinomycin D (7-AAD)) was mixed with the cell suspension at the ratio of $1: 1$, and further incubated at room temperature in the dark for $20 \mathrm{~min}$. Anoikis and apoptotic cells were detected by using Muse Cell Analyzer (Merck Millipore).

Anchorage-independent growth assay. Anchorage-independent cell growth $(\mathrm{AIG})$ was determined using soft-agar assay. Cells $\left(1 \times 10^{4}\right)$ were suspended in $1 \mathrm{ml}$ culture medium containing $0.35 \%$ agar and overlaid onto $1.5 \mathrm{ml}$ culture medium containing $0.8 \%$ agar in 6-well plates. Medium was added every 3 days as a feeder layer. On day 21, photographs of colonies were taken at an original magnification of $40 \times$ and counted using OpenCFU software (opencfu sourceforge.net) at the following settings: threshold of 6 , minimum radius of 8 , and maximum radius of 500 (14).

Immunoblot analysis. Floating cells were harvested by centrifugation at $500 \times g, 4^{\circ} \mathrm{C}$ for $10 \mathrm{~min}$ and then washed with cold phosphate-buffered saline. Attached cells were trypsinized and harvested following the above-mentioned procedure as floating cells. Cell pellets were lysed with RIPA buffer containing Protease Inhibitor Cocktail and phosphatase inhibitors (Sigma-Aldrich) on ice for $30 \mathrm{~min}$. Cell lysates were sonicated and then centrifuged at
$12,000 \times g$ at $4^{\circ} \mathrm{C}$ for $10 \mathrm{~min}$. Protein concentrations were determined using Bradford assay (Bio-Rad Laboratories, Hercules, CA, USA). Samples of protein $(10 \mu \mathrm{g})$ were separated in $12.5 \%$ sodium dodecyl sulfate-polyacrylamide gel electrophoresis (SDSPAGE) and electrophoretically transferred to polyvinylidene difluoride membranes (Millipore). Membranes were then blocked with $3-5 \%$ bovine serum albumin in Tris buffered saline-Tween 20 (TBS-T) for $1 \mathrm{~h}$ and then incubated with primary antibody overnight. The primary antibodies used were poly-ADP ribose polymerase (PARP; 1:1,000), BCL2-like protein 4 (BAX; 1:5,000), heat-shock 60-kDa protein (HSPD1; $1: 10,000), \beta$-actin $(1: 10,000)$, E-cadherin $(1: 2,000), \mathrm{N}$-cadherin $(1: 500)$, vimentin $(1: 1,000)$, integrin $\beta 1(1: 1,000)$, integrin $\beta 4(1: 1,000)$, integrin $\beta 6(1: 1,000)$, integrin $\alpha \mathrm{V}(1: 1,000)$, integrin $\alpha 4(1: 1,000)$, integrin $\alpha 5(1: 1,000)$, cytokeratin $8($ KRT8; 1:5,000) and tumor susceptibility gene 101 (TSG101; 1:5,000). All antibodies were purchased from Cell Signaling Technology, Danvers, MA, USA, except for TSG101 (Abcam, Cambridge, MA, USA) and KRT8 (Merck Millipore). Membranes were washed with TBS-T and then blocked with 5\% skim milk for 30 min before incubation with the corresponding secondary antibody in 5\% skim milk for 45 min. Protein expression signals were achieved using SuperSignal ECL reagent (SigmaAldrich) and detected by x-ray film exposure. Exposed films were scanned, and band intensities were measured in arbitrary units using ImageQuanTL software (GE Healthcare, Chicago, IL, USA).

Proteomic analysis. Attached and floating cells were harvested as described in the immunoblot analysis, and cell pellets were lysed in 2D lysis buffer at room temperature for $1 \mathrm{~h}$. Cell lysates were then sonicated, centrifuged at $12,000 \times g$ at $4^{\circ} \mathrm{C}$ for $10 \mathrm{~min}$, and protein concentrations were determined. Cell lysates $(150 \mu \mathrm{g}$ protein) were separated in Immobiline DryStrips gels strips $(7 \mathrm{~cm}, \mathrm{pH} \mathrm{3-10}$ nonlinear; GE Healthcare) at 7,000 Vh using Ettan IPGphor 3 (GE Healthcare), then strips were equilibrated with two equilibration buffers containing $65 \mathrm{mM}$ dithiothreitol and $135 \mathrm{mM}$ indole-3acetic acid for $10 \mathrm{~min}$ each, respectively, before running on $12.5 \%$ SDS-PAGE. Proteins were visualized using Coomassie Brilliant Blue R-250 (SERVA Electrophoresis GmbH, Heidelberg, Germany). Differential expression of spots between the two culture conditions was analyzed using ImageMaster 2D Platinum software (GE Healthcare). Protein spots with significantly differential expression greater than 1.25 -fold in percent volume were identified using liquid

Figure 1. Properties of anoikis resistance in thyroid cancer cell lines. A: Cell morphology of thyroid cancer cell lines: BCPAP, FTC133 and ARO cells. Micrographs were taken under magnification of 200x (attached cells) or 100× (floating cells), using a phase-contrast inverted microscope. B: Representative flow cytometric results of apoptosis/anoikis in BCPAP, FTC133 and ARO cells when cultured under attached (top paneI) and floating (bottom panel) conditions, respectively. C: Percentage total apoptosis/anoikis from flow cytometric analysis from three biological replicates. Data are the mean $\pm S . D$. Comparisons were analyzed using the Student's t-test. D: Anchorageindependent growth measured using soft-agar assay represented by colony numbers from six biological replicates. Data are the mean $\pm S . D$. Comparisons were analyzed using ANOVA with Tukey's post-hoc test. Significantly different at $* p \leq 0.05, * * p \leq 0.01$, and $* * * p \leq 0.001$. $7 A A D$ : annexin $V$ and 7-aminoactinomycin $D$. 
A



B

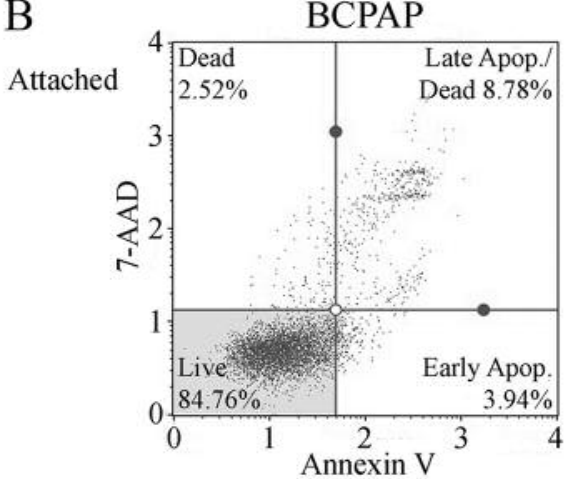

Floating

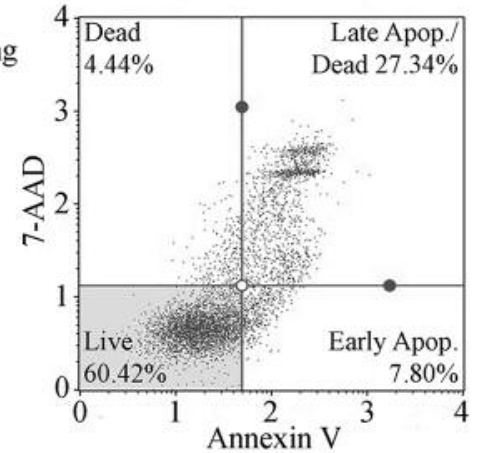

\section{C}

C

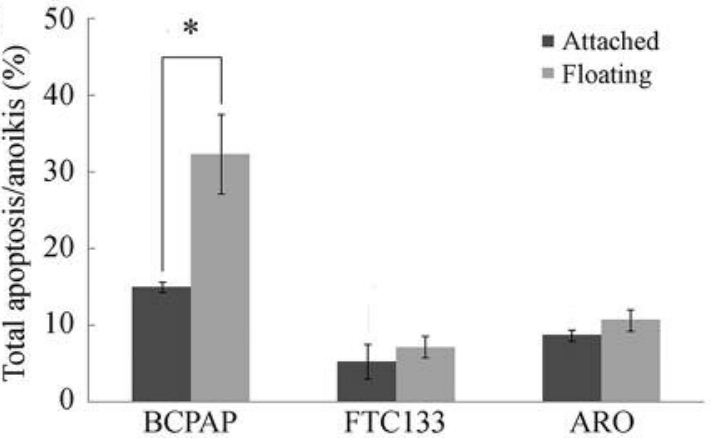

FTC133
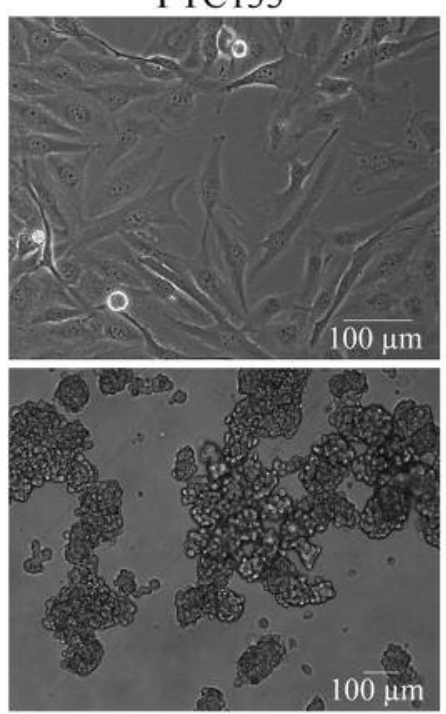

FTC133
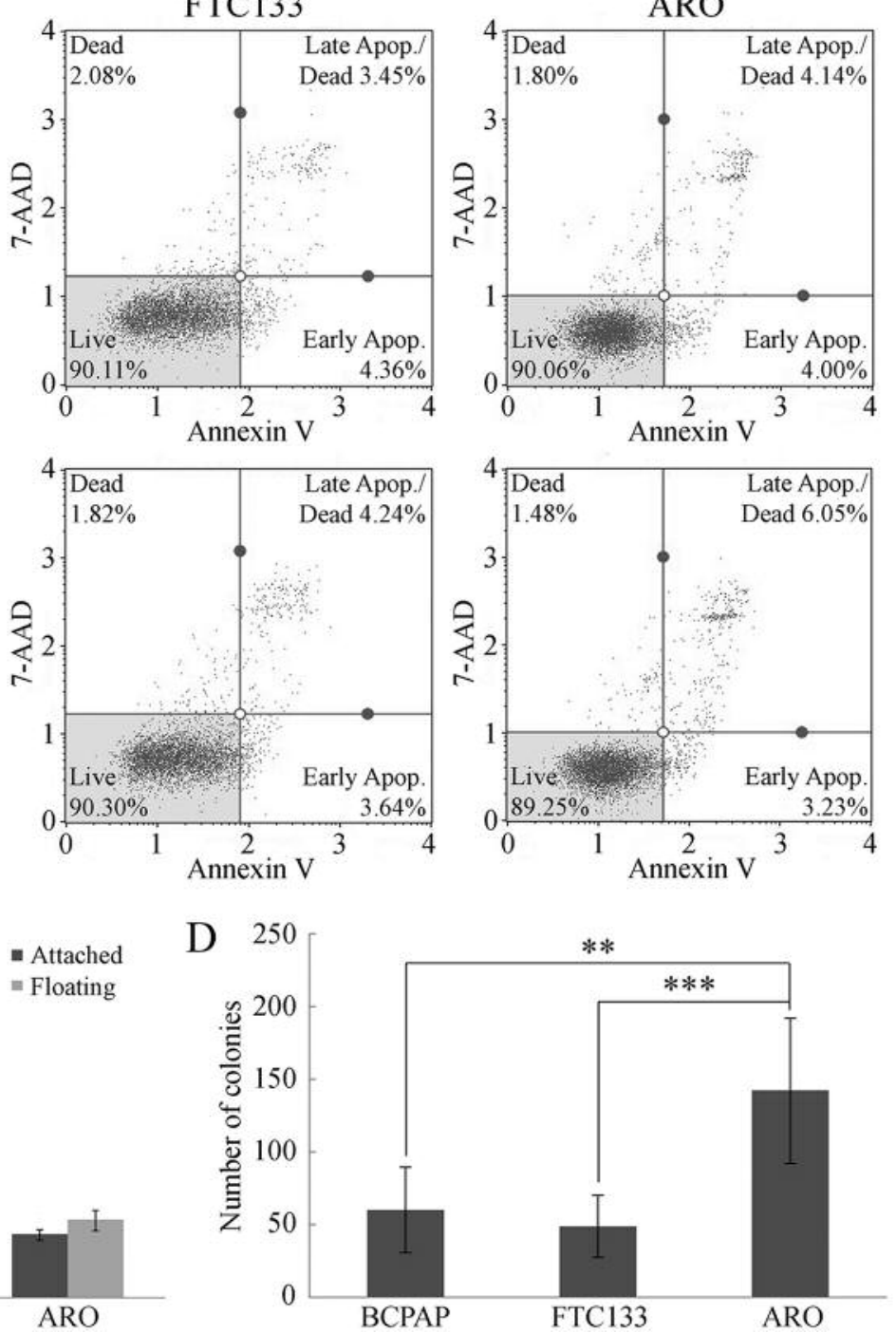
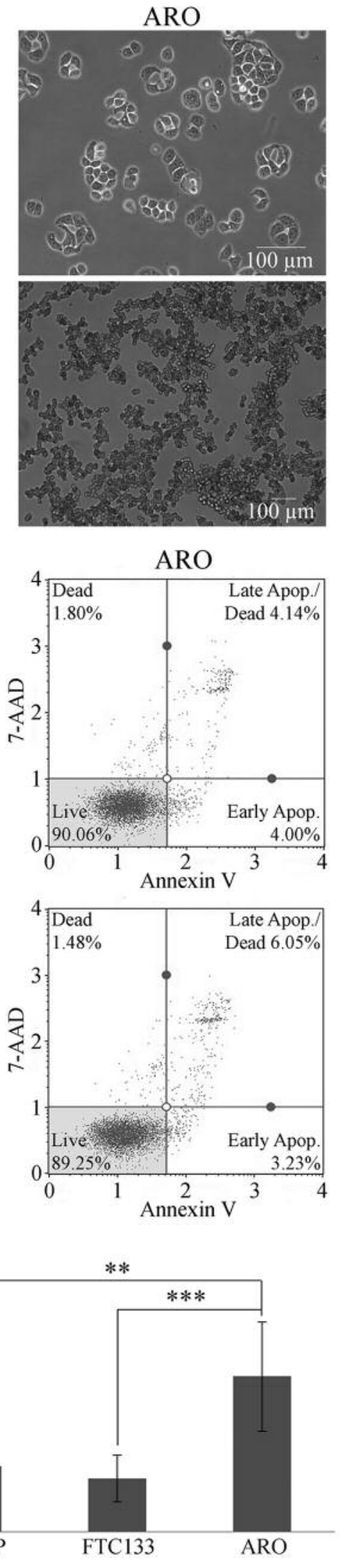
chromatography-tandem mass spectrometry (LC-MS/MS) (Bruker Amazon Speed ETD; Bruker, Billerica, MA, USA) and MASCOT database search, as previously described (4).

Ingenuity Pathway Analysis (IPA). Accession numbers and fold changes of the identified proteins from proteomic analysis were input as a dataset in Ingenuity Pathway Analysis software (Qiagen, Germantown, MD, USA) to predict the relevant molecular networks. The analysis criteria were set as follows: Reference set, Ingenuity Knowledge Base (genes only); Relationship to consider, Direct and Indirect relationships; Networks, interaction; Data source, all; Confidence, Experimentally Observed; Species, Human; Tissues and cell lines, Other cell line; and Mutation, all.

Small interfering RNA (siRNA) knockdown. Two sequences of Silencer Select Pre-designed siRNAs (Ambion, Naugatuck, CT, USA) targeted against human TSG101 (siTSG1: ID s14439 and siTSG2: ID s14440) were used to knockdown TSG101 expression. Medium GC-content Silencer Select Negative Control (Ambion) was used as the negative control or scramble. The siRNAs were transfected into cell lines by reverse transfection technique using Lipofectamine 2000 (Invitrogen), following the manufacturer's instructions. In brief, $3 \times 10^{5}$ cells were suspended in $2 \mathrm{ml}$ of antibiotic-free media containing $5 \mathrm{nM}$ siRNA and seeded into uncoated or polyHEMA-coated 6-well plates, then cultured for $72 \mathrm{~h}$ before running further experiments.

Statistical analysis. All experiments were performed in at least three independent biological replicates and data were presented as mean \pm S.D. Student's $t$-test was used when comparing data of attached cells and floating cells. Soft-agar assay, proteomics and immunoblots of candidate proteins were analyzed using ANOVA with Tukey's posthoc test. Pearson correlation was used to determine the correlation between the expression of TSG101 and total apoptosis/anoikis. Values of $p \leq 0.05$, were considered to be statistically significant.

\section{Results}

Cell morphology and growth of attached and floating cancer cells. Initially, non-adherent culture was obtained using polyHEMA-coated plates to establish floating thyroid cancer cells $(12,13)$. Under adherent condition (monolayer culture), BCPAP and ARO cells appeared as round-shaped epitheliallike cells, whereas FTC133 cells were elongated and fibroblast-like (Figure 1A) (4). Under non-adherent condition, floating cells of all three cell lines aggregated into floating colonies with different aggregate densities; the colonies of BCPAP and FTC133 cells were more compact than the colonies of ATC cells (Figure 1A).

The anoikis resistance potential of the three thyroid cancer cell lines was confirmed using a flow cytometric analysis to determine the number of annexin V-positive cells after $24 \mathrm{~h}$ of cultivation under both culture conditions. Only BCPAP cells showed a significant increase in cell death under non-adherent condition, from $12 \pm 2 \%$ in attached cells to $35 \pm 3 \%$ in floating cells (Figure $1 \mathrm{~B}$ and $\mathrm{C}$ ). In contrast, there was no significant increase in cell death of FTC133 and ARO cells when cultured under non-adherent condition compared to adherent condition (Figure 1B and C), indicating that FTC133 and ARO cells were more resistant to anoikis than BCPAP cells.

Anchorage-independent growth. Anoikis resistance is required for AIG and is correlated with tumorigenicity and metastatic potential of cancer cells $(15,16)$. AIG was examined using soft-agar assay. Although all the cell lines formed colonies in soft-agar, the number of ARO colonies was significantly higher than those of the other two cell lines (Figure 1D), suggesting that ARO exhibited the highest capacity for AIG among the tested cell lines.

Taken together, our data indicated different potential for anoikis resistance and AIG capacity among the three thyroid cancer cell lines, in ascending order for BCPAP (papillary type), FTC133 (follicular type), and ARO (anaplastic type) cell lines, consistent with their metastatic potential as observed in clinical pathology (8). Additionally, our results supported the use of the ARO cell line as a suitable model for further studies into the mechanisms of anoikis resistance and AIG in metastatic thyroid cancer.

Identification of key proteins involved in anoikis resistance of thyroid cancer cells. After $24 \mathrm{~h}$ of culture under adherent or non-adherent conditions, attached and floating ARO cells were subjected to proteomic analysis, according to the protocol in our previous study (4). Twenty-five protein spots showed significant differences in expression by more than 1.25-fold; 14 spots decreased in expression and 11 spots increased in expression in floating cells when compared to those of attached cells (Figure 2). These spots were identified by LC-MS/MS and MASCOT database search (Table I) and then classified based on their functions, namely into those related to cell proliferation, stress response, cellular movement, apoptosis, and glycolysis (Figure 3A).

In order to identify critical proteins involved in anoikis resistance of ARO cells, the dataset of identified proteins was analyzed using IPA. IPA revealed cell death and survival to be the most relevant biological network, with a score of 11 , and six molecules from our identified proteins were categorized into three functional groups (Figure 3B); namely lamin A/C (LMNA) and KRT8, involved in cellular movement $(17,18)$; stress-induced phosphoprotein 1 (STIP1) and HSPD1, involved in stress response $(19,20)$ : and 14-3-3 epsilon (YWHAE) and TSG101, involved in apoptosis (21, 22). HSPD1, KRT8 and TSG101 were selected as candidate proteins from each functional group. According to IPA analysis, HSPD1 interacts with multiple proteins from different cellular functions that are involved with apoptosis, such as stress response (heat-shock proteins) and proapoptosis (BAX). KRT8 and TSG101 were selected because the expression level of KRT8 was higher than that of the other five proteins and TSG101 is involved with the 

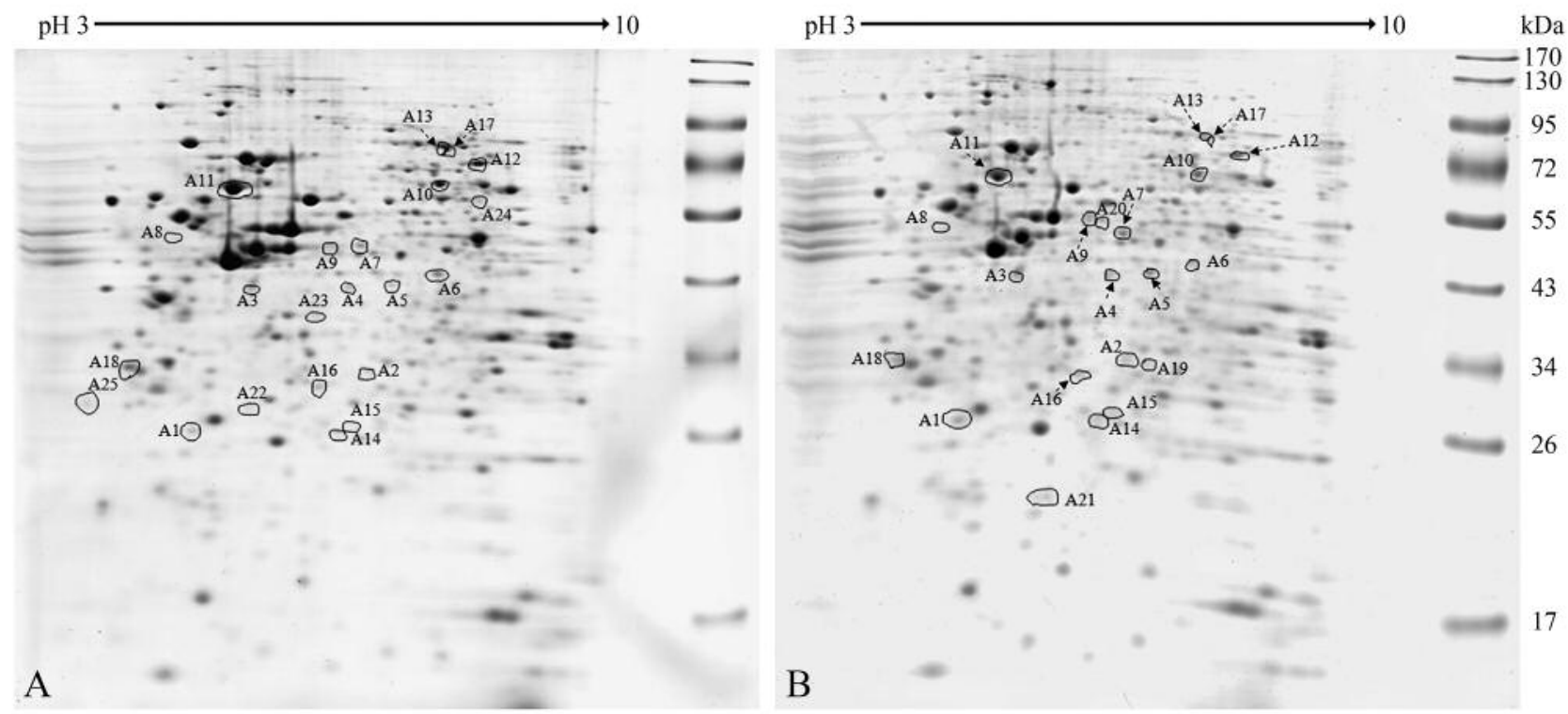

Figure 2. Differential protein expression in ARO cells using proteomics. Panels A and B are representative two-dimensional gels of attached and floating ARO cells, respectively. There were 25 spots with statistically significant differences in expression, as analyzed using ANOVA, and with intensities greater than 1.25-fold. Significantly different at $p \leq 0.05$ when comparing percent volumes of attached and floating cells.

progression of multiple cancer types. Moreover, IPA suggested the involvement of BAX in anoikis resistance in floating ARO cells.

Validation of proteomic and network analyses. The expression of candidate proteins was determined for the three thyroid cancer cell lines by immunoblotting, as shown in Figure 3C. The expression of HSPD1 was slightly decreased in all cell lines when cultured under nonadherent condition for $24 \mathrm{~h}$. KRT 8 was detected only in ARO cells, consistent with a previous report of KRT8 overexpression in patient-derived ATC cell lines (23). KRT8 expression was reduced in floating cells, in contrast to proteomics results. Previous studies revealed HSPD1 and KRT8 to be apoptotic drivers $(23,24)$ and their downregulation would support anoikis resistance. Unfortunately, our immunoblot results showed no statistically significant differences in HSPD1 and KRT8 expression between attached and floating cells, thereby diminishing their importance in anoikis resistance. Interestingly, TSG101 expression was increased in floating cells of all cell lines, with statistical significance in FTC133 and ARO cells, consistent with the proteomics results.

Role of TSG101 in anoikis resistance. To elucidate the role of TSG101 in anoikis resistance, siRNA-mediated knockdown of TSG101 was performed. When evaluating the incubation time, 72-h incubation was most suitable at suppressing TSG101 protein expression. TSG101 expression significantly decreased as a function of time (data not shown) and decreased dramatically at 72-h post-transfection with siTSG101, but not in siRNA control cells (scramble) (Figure 4A). After 72-h post siTSG101 transfection, floating ARO cells displayed significant up-regulation of the proapoptotic protein BAX compared to attached and floating cells transfected with scramble siRNAs. This increase correlated with the increase in the expression of cleaved PARP, a marker of apoptosis (Figure 4A), indicating that anoikis occurred in the siTGS101-transfected floating cells.

The consequence of TSG101 knockdown in anoikis was confirmed using flow cytometric analysis. No significant differences were found in the levels of apoptosis/anoikis between adherent and non-adherent cultures of scrambletransfected cells (Figure 4B and C). In contrast, the level of anoikis was significantly increased in siTSG101transfected floating cells $(30 \pm 2 \%$ and $25 \pm 2 \%$ anoikis for siTSG101 sequence 1 and 2, respectively), compared with scramble-transfected floating cells ( $18 \pm 1 \%$ anoikis) (Figure 4B and C). Moreover, statistical analysis using Pearson correlation suggested a negative correlation between TSG101 expression and total apoptosis/anoikis with $\mathrm{r}=-0.767$ and $p=0.004$. These results confirmed the importance of TSG101 in anoikis resistance in the ATC cell line, ARO. 



Figure 3. Continued 

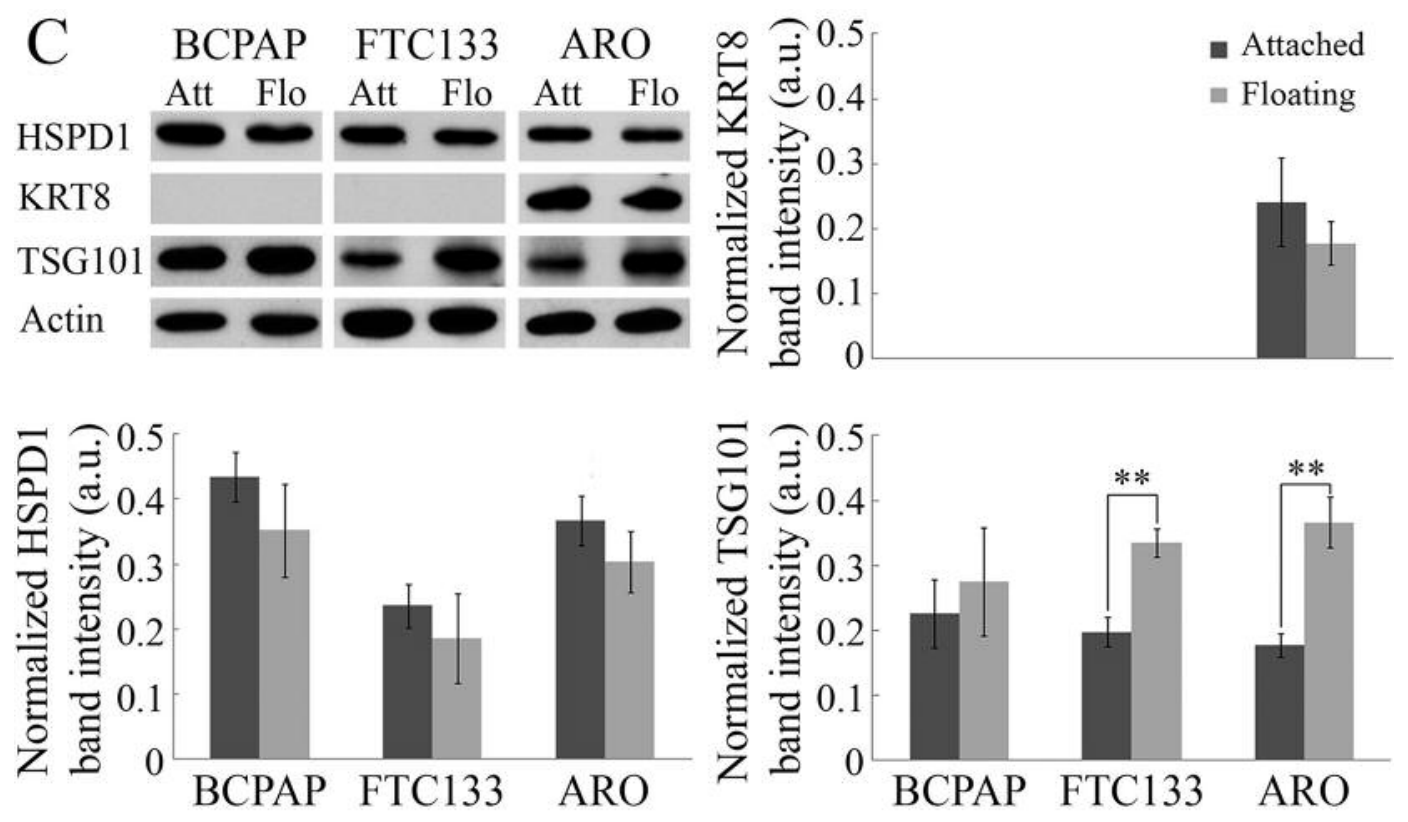

Figure 3. Identification of essential proteins involved in anoikis resistance of ARO cells. A: Volcano plot of differentially expressed proteins under attached and floating conditions of ARO cells using two-dimensional gel proteomic analysis. The identified proteins (Table I) were classified based on their functions into five groups, including cell proliferation (red), stress response (blue), apoptosis (yellow), cellular movement (green) and glycolysis (light blue). B: Ingenuity Pathway Analysis of differentially expressed proteins from the proteomic analysis. Red represents proteins with increased expression in floating cells compared to those in attached cells, whereas green represents proteins with decreased expression. The following proteins were identified in the network by IPA: Type-1A angiotensin 2 receptor (AGTR1), BCL-2 like protein 4 (BAX), G1/S-specific cyclin D1 (CCND1), T-complex protein 1E (CCT5), M-phase inducer phosphatase 3 (CDC25C), cyclin-dependent kinase 6 (CDK6), cyclin-dependent kinase inhibitor 1 (CDKN1A), catenin $\beta 1$ (CTNNB1), elongation factor1 $\alpha 1$ (EEF1A1), glycogen synthase kinase 3 $\beta$ (GSK3), heat shock protein 90 $\alpha$ (HSP90AA1), heat shock protein $90 \beta$ (HSP90AB1), heat shock cognate 71-kDa protein (HSPA8), heat shock 70-kDa protein 1A/1B (HSPA1A/HSPA1B), heat shock 60-kDa protein (HSPD1), integrin a 5 precursor (ITGA5), potassium voltage-gated channel subfamily $H$ member 2 (KCNH2), cytokeratin 8 (KRT8), cytokeratin 18 (KRT18), lamin A/C (LMNA), mitogen-activated protein kinase kinase kinase 3 (MAP3K3), mechanistic target of rapamycin (MTOR), Parkin co-regulated gene protein (PACRG), peroxiredoxin 6 (PRDX6), sodium-dependent serotonin transporter (SLC6A4), sterol regulatory element-binding transcription factor 1 (SREBF1), stress-induced phosphoprotein 1 (STIP1), tumor necrosis factor (TNF), tumor protein p53 (TP53), tumor susceptibility gene 101 protein (TSG101), WD repeat-containing protein 82 (WDR82), 14-3-3 $\beta$

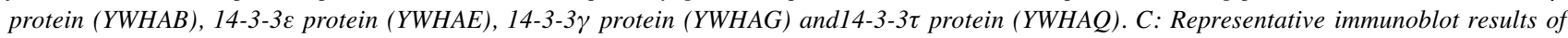
proteins from each functional group: HSPD1 (stress response), KRT8 (cellular movement), and TSG101 (apoptosis), and quantitative analysis using band intensities (arbitrary unit) normalized by that of actin (loading control). Data are the mean \pm S.D. Comparisons were analyzed using the Student's t-test. Significantly different at **p $\leq 0.01$.

Investigation of the mechanism underlying TSG101-mediated anoikis resistance. We evaluated two potential promising mechanisms of anoikis resistance: epithelial-mesenchymal transition (EMT) and changes in the integrin expression profile ("integrin switch") (1). The down-regulation of E-cadherin together with the up-regulation of $\mathrm{N}$-cadherin and vimentin are characteristics of EMT. However, we observed the up-regulation of E-cadherin expression in floating ARO cells rather than a decrease (Figure 5A), together with the lack of $\mathrm{N}$-cadherin and vimentin expression (data not shown). Regarding the integrin switch, no significant changes in expression of integrins $\beta 1, \beta 4$ and $\alpha \mathrm{V}$ were observed (Figure 5B) and expression of integrins $\alpha 4, \alpha 5$ and $\beta 6$ was not detected (data not shown). Therefore, the upregulation of E-cadherin and the lack of changes in the expression of multiple integrins in floating ARO cells suggests that TSG101 may not trigger anoikis resistance in floating cells through EMT and integrin switch.

\section{Discussion}

In this study, we utilized proteomics together with nonadherent cultures to identify key proteins in anoikis resistance of thyroid cancer cell lines. Overexpression of TSG101 protein was found to be essential for anoikis resistance of thyroid cancer cells with high metastatic potential. As far as we are 
Table I. Identification of differentially expressed proteins by LC-MS/MS and Mascot database search.

\begin{tabular}{|c|c|c|c|c|c|c|c|c|c|}
\hline $\begin{array}{l}\text { Spot } \\
\text { ID }\end{array}$ & $\begin{array}{c}\text { Accession } \\
\text { no. }\end{array}$ & $\begin{array}{l}\text { Protein name } \\
\text { (symbol) }\end{array}$ & $\begin{array}{l}\mathrm{MW}(\mathrm{Da}) / \\
\mathrm{pI}\end{array}$ & Coverage & $\begin{array}{l}\text { Peptide } \\
\text { match }\end{array}$ & $\begin{array}{l}\text { Mascot } \\
\text { score }\end{array}$ & $\begin{array}{l}\text { Fold } \\
\text { change }\end{array}$ & $p$-Value & Function \\
\hline A1 & gil179955 & $\begin{array}{c}\text { Catechol-O-methyltransferase } \\
\text { (COMT) }\end{array}$ & $30,433 / 5.26$ & 15 & 3 & 168 & +1.43 & 0.04 & $\begin{array}{c}\text { Stress } \\
\text { response }\end{array}$ \\
\hline A2 & gil4758484 & $\begin{array}{c}\text { Glutathione S-transferase } \\
\text { omega-1 (GSTO1) }\end{array}$ & $27,833 / 6.23$ & 31 & 9 & 344 & +1.51 & 0.05 & $\begin{array}{l}\text { Stress } \\
\text { response }\end{array}$ \\
\hline A3 & gil7305503 & $\begin{array}{c}\text { Stomatin-like protein } 2 \\
\text { (GLRX3) }\end{array}$ & $38,624 / 6.88$ & 21 & 8 & 304 & -1.27 & 0.03 & $\begin{array}{c}\text { Cell } \\
\text { proliferation }\end{array}$ \\
\hline A4 & gil187456 & $\begin{array}{l}\text { Macrophage-capping } \\
\text { protein (CAPG) }\end{array}$ & $38,779 / 5.88$ & 11 & 5 & 156 & +1.54 & 0.01 & $\begin{array}{l}\text { Cellular } \\
\text { movement }\end{array}$ \\
\hline A5 & gil13899354 & $\begin{array}{l}\text { RNA-binding protein } \\
\text { 4B (RBM4) }\end{array}$ & $40,466 / 6.28$ & 22 & 8 & 336 & +2.05 & 0.03 & $\begin{array}{l}\text { Stress } \\
\text { response }\end{array}$ \\
\hline A6 & gil55956919 & $\begin{array}{l}\text { Heterogeneous nuclear } \\
\text { ribonucleoprotein A/B } \\
\text { (hnRNPA/B) }\end{array}$ & $36,059 / 6.49$ & 18 & 6 & 267 & -1.26 & 0.05 & $\begin{array}{c}\text { Cell } \\
\text { proliferation }\end{array}$ \\
\hline A7 & gil5454140 & $\begin{array}{l}\text { Tumor susceptibility } \\
\text { gene } 101 \text { protein } \\
\text { (TSG101) }\end{array}$ & $44,088 / 6.06$ & 15 & 5 & 250 & +1.31 & 0.04 & Apoptosis \\
\hline A8 & gil4503571 & Alpha-enolase (ENO1) & $47,481 / 7.01$ & 17 & 6 & 323 & +1.56 & 0.01 & Glycolysis \\
\hline A9 & gil119617057 & $\begin{array}{l}\text { Cytokeratin } 8 \\
\text { (KRT8) }\end{array}$ & $57,829 / 5.41$ & 39 & 22 & 929 & -1.42 & 0.04 & $\begin{array}{l}\text { Cellular } \\
\text { movement }\end{array}$ \\
\hline A 10 & gil544063423 & $\begin{array}{c}\text { Stress-induced- } \\
\text { phosphoprotein } 1 \text { (STIP1) }\end{array}$ & $68,721 / 7.81$ & 23 & 19 & 568 & -1.20 & 0.03 & $\begin{array}{l}\text { Stress } \\
\text { response }\end{array}$ \\
\hline A11 & gil31542947 & $\begin{array}{l}\text { Heat shock } 60-\mathrm{kDa} \\
\text { protein (HSPD1) }\end{array}$ & $61,187 / 5.70$ & 53 & 33 & 1,472 & -1.24 & 0.03 & $\begin{array}{c}\text { Stress } \\
\text { response }\end{array}$ \\
\hline A12 & gil768008730 & $\begin{array}{l}\text { Heterogeneous nuclear } \\
\text { ribonucleoprotein L } \\
\text { (hnRNPL) }\end{array}$ & $58,068 / 7.25$ & 20 & 8 & 395 & -1.52 & 0.01 & $\begin{array}{l}\text { Cellular } \\
\text { movement }\end{array}$ \\
\hline A13 & gil119573383 & $\begin{array}{c}\text { Lamin } \mathrm{A} / \mathrm{C} \\
\text { (LMNA) }\end{array}$ & $87,829 / 8.91$ & 45 & 37 & 1850 & -1.57 & 0.03 & $\begin{array}{l}\text { Cellular } \\
\text { movement }\end{array}$ \\
\hline A14 & gil332837089 & $\begin{array}{c}\text { Glutathione S-transferase } \\
\text { P (GSTP1) }\end{array}$ & $23,555 / 5.43$ & 26 & 4 & 259 & +2.04 & 0.01 & $\begin{array}{l}\text { Stress } \\
\text { response }\end{array}$ \\
\hline A 15 & gil4504517 & $\begin{array}{l}\text { Heat shock protein } \\
\text { beta-1 (HSPB1) }\end{array}$ & $22,826 / 5.98$ & 37 & 9 & 320 & +1.52 & 0.02 & $\begin{array}{c}\text { Stress } \\
\text { response }\end{array}$ \\
\hline A16 & gil4507953 & $\begin{array}{l}\text { 14-3-3 protein } \\
\text { zeta/delta (YWHAZ) }\end{array}$ & $27,899 / 4.73$ & 37 & 9 & 501 & -1.26 & 0.04 & Apoptosis \\
\hline A 17 & gil4504035 & GMP synthase (GMPS) & $77,408 / 6.42$ & 39 & 22 & 996 & -1.72 & 0.00 & Apoptosis \\
\hline A18 & gil5803225 & $\begin{array}{l}\text { 14-3-3 protein } \\
\text { epsilon (YWHAE) }\end{array}$ & $29,326 / 4.63$ & 43 & 12 & 594 & -2.00 & 0.01 & Apoptosis \\
\hline A19 & gil4758484 & $\begin{array}{l}\text { Glutathione S-transferase } \\
\text { omega-1 (GSTO1) }\end{array}$ & $27,833 / 6.23$ & 15 & 4 & 148 & Present & 0.02 & $\begin{array}{l}\text { Stress } \\
\text { response }\end{array}$ \\
\hline A 20 & gil181573 & $\begin{array}{l}\text { Cytokeratin } 8 \\
\text { (KRT8) }\end{array}$ & $53,529 / 5.52$ & 15 & 8 & 410 & Present & 0.01 & $\begin{array}{l}\text { Cellular } \\
\text { movement }\end{array}$ \\
\hline A 21 & gil32189392 & $\begin{array}{l}\text { Peroxiredoxin } 2 \\
\quad(\text { PRDX2) }\end{array}$ & $22,049 / 5.66$ & 23 & 7 & 341 & Present & 0.00 & $\begin{array}{l}\text { Stress } \\
\text { response }\end{array}$ \\
\hline A 22 & gil5031653 & $\begin{array}{l}\text { Pre-mRNA-splicing } \\
\text { factor SPF27 (BCAS2) }\end{array}$ & $26,229 / 5.48$ & 16 & 3 & 160 & Absent & 0.00 & Apoptosis \\
\hline A 23 & gil4506667 & $\begin{array}{l}\text { 60S acidic ribosomal } \\
\text { protein (RPLP0) }\end{array}$ & $34,423 / 5.71$ & 23 & 6 & 265 & Absent & 0.00 & $\begin{array}{c}\text { Cell } \\
\text { proliferation }\end{array}$ \\
\hline A 24 & $\begin{array}{l}\text { No data } \\
\text { available }\end{array}$ & - & - & - & - & - & - & - & - \\
\hline A 25 & gil5453880 & $\begin{array}{c}\text { Acidic leucine-rich } \\
\text { nuclear phosphoprotein } \\
32 \text { (LANP) }\end{array}$ & $28,682 / 3.99$ & 34 & 11 & 427 & Absent & 0.05 & $\begin{array}{c}\text { Cell } \\
\text { proliferation }\end{array}$ \\
\hline
\end{tabular}

aware, this is the first report to show the novel role of TSG101 overexpression in anoikis resistance of thyroid cancer cells.

TSG101 (also known as VPS23) is an integral component of the first complex of the endosomal sorting complex required for transport pathway (ESCRT-I) by assisting in the biogenesis of vesicles or multivesicular bodies (MVB), e.g. endosomes and exosomes (25). TSG101 was originally identified as a tumor-suppressor gene (26), but recent studies showed its 

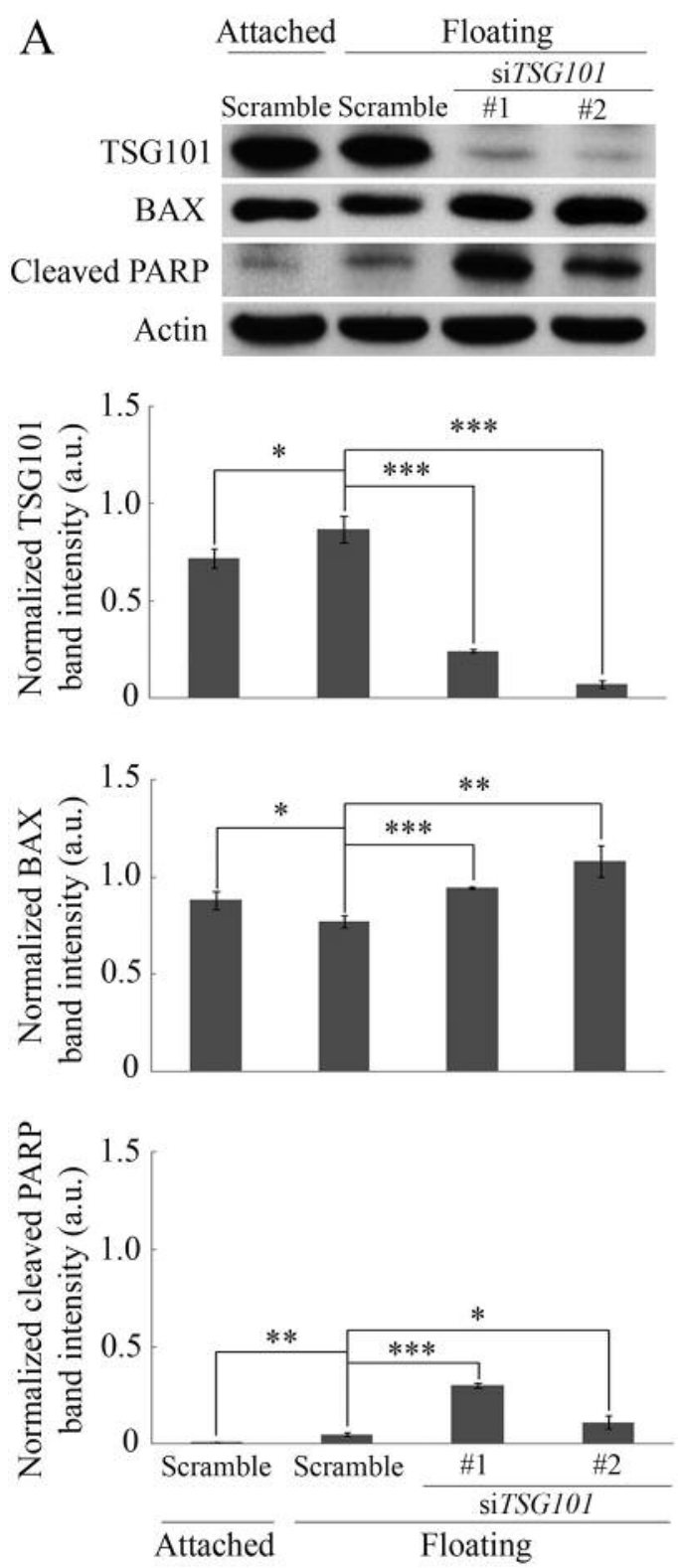
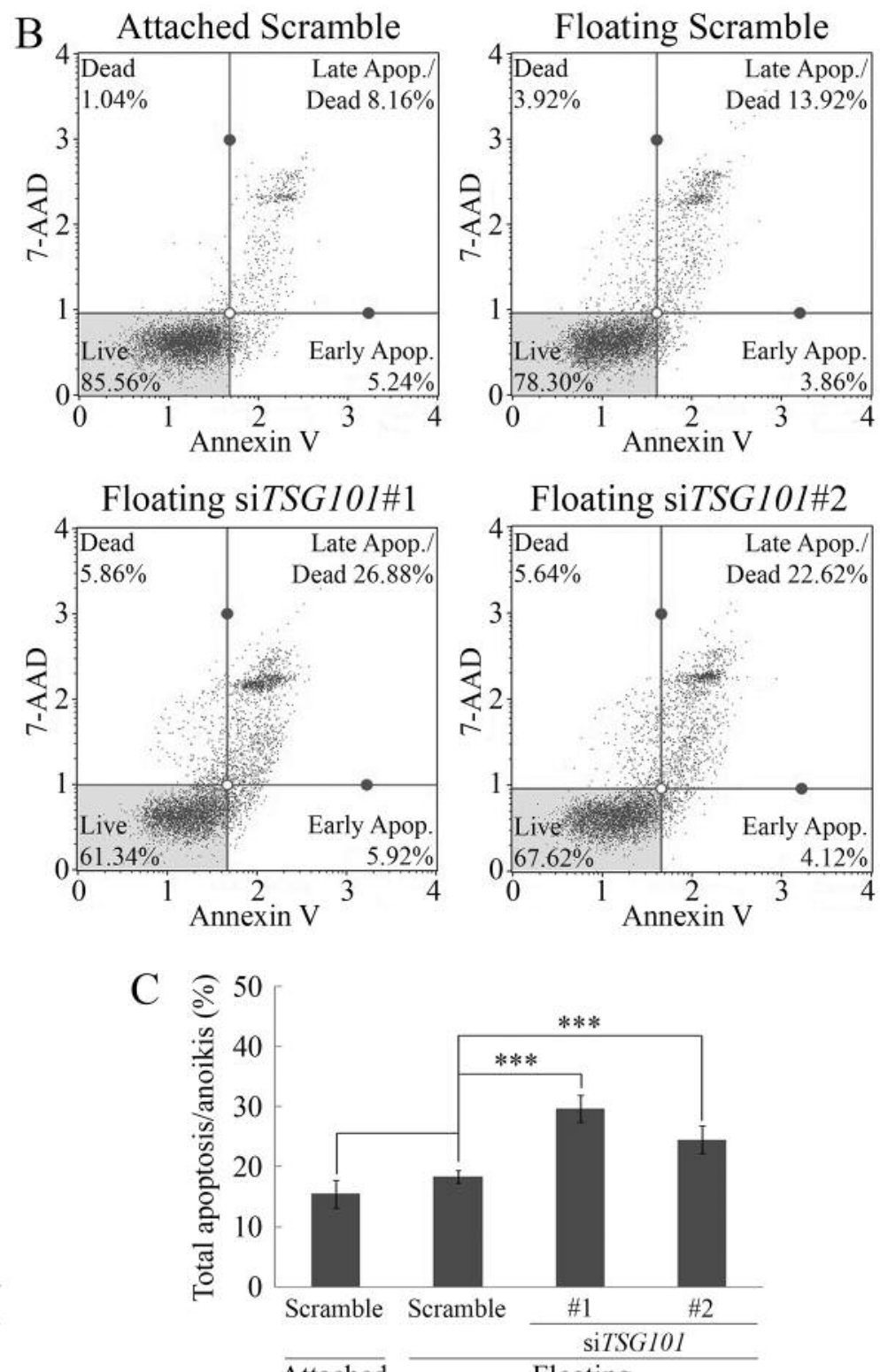

$\overline{\text { Attached }}$

Floating

Figure 4. Importance of tumor susceptibility gene 101 protein (TSG101) in anoikis resistance of ARO cells. A: Expression of TSG101, BCL-2 like protein 4 (BAX) and cleaved poly-ADP ribose polymerase (PARP) in ARO cells after 72-h siRNA-mediated knockdown of TSG101. Band intensities (arbitrary unit) were normalized by that of actin (loading control). B: Flow cytometric analysis of apoptosis/anoikis (\%) in ARO cells after TSG101knockdown for 72 h.C: Quantitative analysis of flow cytometric results of percentage total apoptosis/anoikis, indicating significantly increased total apoptosis/anoikis in cells with siRNA-mediated knockdown of TSG101. Comparisons of attached with floating scramble-siRNA-transfected cells, and floating scramble-siRNA-transfected cells with siTSG101-transfected cells were analyzed using Student t-test. Data are the mean $\pm S . D$. Significantly different at $* p \leq 0.05, * * p \leq 0.01$, and $* * * p \leq 0.001$. 7AAD: annexin V and 7-aminoactinomycin D.

oncogenic role in several types of cancer. siRNA-mediated down-regulation of TSG101 triggered cell-cycle arrest in breast cancer, prostate cancer and hepatocellular carcinomas (27-29). Our results also support the oncogenic role of TSG101 as a regulator of anoikis resistance in thyroid cancer cells.
EMT and integrin switch have been proposed to be mechanisms underlying anoikis resistance. Down-regulation of E-cadherin during EMT may promote cell survival by reducing the formation of the death-inducing signaling complex (DISC) (30). Likewise, switching of integrin 

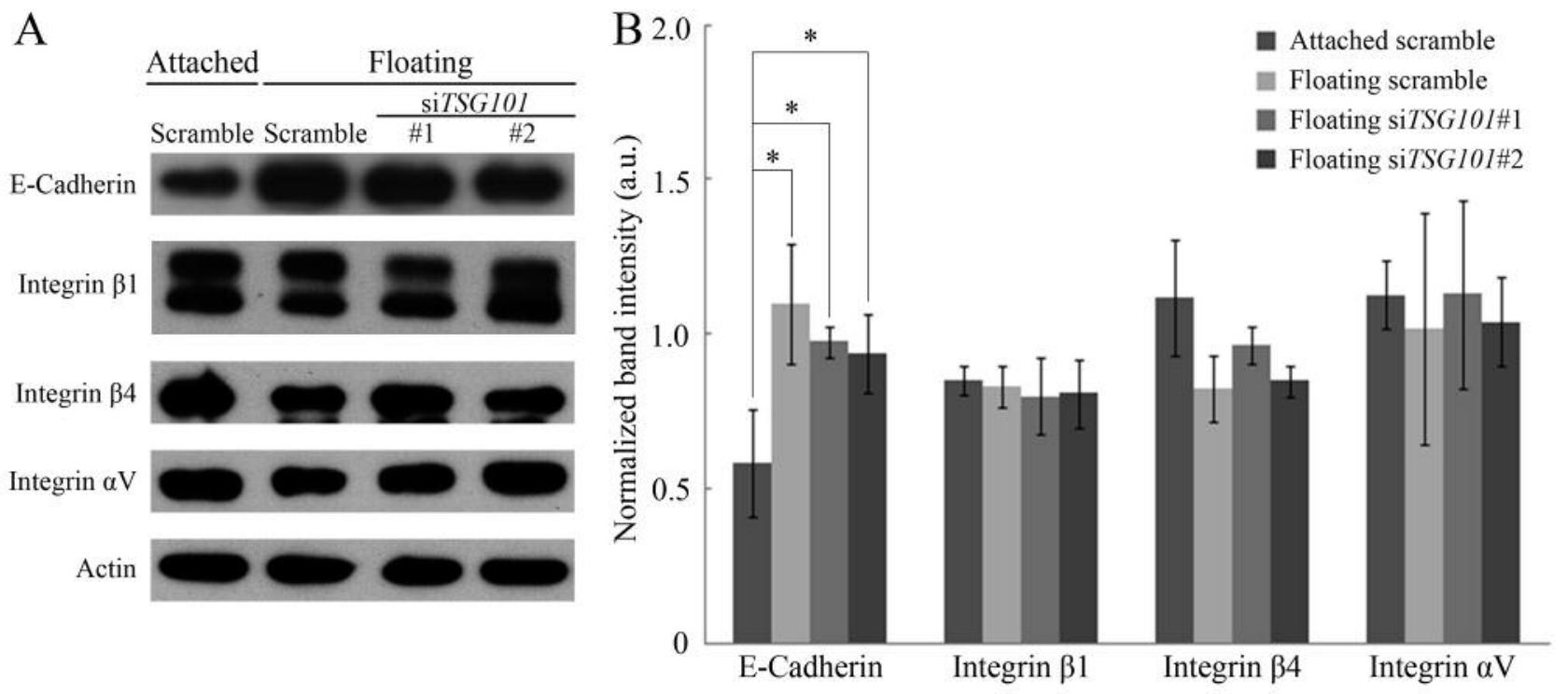

Figure 5. Investigation into two proposed mechanisms of anoikis resistance using tumor susceptibility gene 101 (TSG101) silencing. A: Immunoblots of E-cadherin, an epithelial-mesenchymal transition marker, and integrins after 72-h siRNA-mediated knockdown of TSG101. B: Band intensities (arbitrary unit) of the investigated proteins normalized by that of actin (loading control). Comparisons of attached with floating scramble-siRNAtransfected and siTSG101-transfected cells were analyzed using the Student's $t$-test. Data are the mean \pm S.D. *Significantly different at $p \leq 0.05$.

expression by the down-regulation of intrinsic apoptosis inducer, $\alpha \mathrm{V} \beta 5$ integrin, along with the up-regulation of prosurvival $\alpha \mathrm{V} \beta 6$ integrin, has been shown to support the acquisition of anoikis resistance (31). Additionally, upregulation of $\beta 4$ integrin can promote cell survival through constitutive activation of phosphoinositide 3-kinase survival pathway (1). However in our study, an increase in E-cadherin expression in floating thyroid cancer cells transfected with either siRNA control or siTSG101, rather than a decrease, as well as the lack of significant changes in expression of integrin types, suggests that TSG101 does not regulate anoikis resistance through EMT or integrin switch.

Another mechanism that may induce anoikis resistance is the shutdown of apoptotic signaling. Activation of cellsurface death receptors has been reported to trigger anoikis in normal cells (3). In addition, endocytosis is important in preventing prolonged activation of cell surface receptors. In mitogenic signaling, for example, activated cell surface growth factor receptors are endocytosed, and subsequently sorted to lysosomes for degradation (32). Therefore, we hypothesize that endocytosis of death receptors has the potential to be a mechanism by which cancer cells resist anoikis. TSG101 is involved in vesicular biogenesis, endocytosis, membrane trafficking and receptor recycling (33). Moreover, defective mutations of TSG101 had been shown to impair trafficking of endocytosed epidermal growth factor (EGF) receptors to lysosomes, which resulted in decreased degradation of EGF receptors and prolonged mitogenic signaling in cells (32). Therefore, we intend to further explore the possibility of the involvement of TSG101 overexpression in anoikis resistance via an increase in the sequestration of death receptors through endocytosis.

In summary, we provide the first evidence on the significance of TSG101 in anoikis resistance of metastatic thyroid cancer cells, which may be a new molecular therapeutic target against metastatic thyroid cancer.

\section{Conflicts of Interest}

The Authors declare that there are no conflicts of interest in regard to this study.

\section{Acknowledgements}

This work was supported by Chulabhorn Research Institute [Grant numbers BC 2008-02 and BC 2017-01] and Chulabhorn Graduate Institute, Thailand. The Authors very much appreciate Professor Johan Lillehaug from University of Bergen, Norway for providing the thyroid cancer cell lines.

\section{References}

1 Paoli P, Giannoni E and Chiarugi P: Anoikis molecular pathways and its role in cancer progression. Biochim Biophys Acta Mol Cell Res 1833(12): 3481-3498, 2013. 
2 Gupta GP and Massagué J: Cancer metastasis: Building a framework. Cell 127(4): 679-695, 2006.

3 Simpson CD, Anyiwe K and Schimmer AD: Anoikis resistance and tumor metastasis. Cancer Lett 272(2): 177-185, 2008.

4 Paricharttanakul NM, Saharat K, Chokchaichamnankit D, Punyarit P, Srisomsap C and Svasti J: Unveiling a novel biomarker panel for diagnosis and classification of well-differentiated thyroid carcinomas. Oncol Rep 35(4): 2286-2296, 2016.

5 American Cancer Society: Cancer Treatment and Survivorship Facts \& Figures 2016-2017. Atlanta: American Cancer Society, 2016.

6 Siegel RL, Miller KD and Jemal A: Cancer statistics, 2016. CA Cancer J 66(1): 7-30, 2016.

7 Miller KD, Siegel RL, Lin CC, Mariotto AB, Kramer JL, Rowland JH, Stein KD, Alteri R and Jemal A: Cancer treatment and survivorship statistics, 2016. CA Cancer J 66(4): 271-289, 2016.

8 Viglietto G and De Marco C: Molecular biology of thyroid cancer. In: Contemporary Aspects of Endocrinology. DiamantiKandarakis E (eds): InTech; c2011, pp. 189-234, 2011.

9 Are C and Shaha AR: Anaplastic thyroid carcinoma: Biology, pathogenesis, prognostic factors, and treatment approaches. Ann Surg Oncol 13(4): 453-464, 2006.

10 Anania MC, Miranda C, Vizioli MG, Mazzoni M, Cleris L, Pagliardini S, Manenti G, Borrello MG, Pierotti MA and Greco A: S100a11 overexpression contributes to the malignant phenotype of papillary thyroid carcinoma. J Clin Endocrinol Metab 98(10): E1591-E1600, 2013.

11 Zhang W-L, Lv W, Sun S-Z, Wu X-Z and Zhang J-H: Mir-206 inhibits metastasis-relevant traits by degrading MRTF-A in anaplastic thyroid cancer. Int J Oncol 47(1): 133-142, 2015.

12 Jensen K, Patel A, Klubo-Gwiezdzinska J, Bauer A and Vasko $\mathrm{V}$ : Inhibition of gap junction transfer sensitizes thyroid cancer cells to anoikis. Endocr Relat Cancer 18(5): 613-626, 2011.

13 Atjanasuppat K, Lirdprapamongkol K, Jantaree P and Svasti J: Non-adherent culture induces paclitaxel resistance in h460 lung cancer cells via ERK-mediated up-regulation of $\beta \mathrm{IVa}$-tubulin. Biochem Biophys Res Commun 466(3): 493-498, 2015.

14 Champattanachai V, Netsirisawan P, Chaiyawat P, Phueaouan T, Charoenwattanasatien R, Chokchaichamnankit D, Punyarit P, Srisomsap C and Svasti J: Proteomic analysis and abrogated expression of $O$-GlcNAcylated proteins associated with primary breast cancer. J Proteom 13(14): 2088-2099, 2013.

15 Colburn NH, Bruegge WV, Bates J, Gray R, Rossen J, Kelsey $\mathrm{W}$ and Shimada T: Correlation of anchorage-independent growth with tumorigenicity of chemically transformed mouse epidermal cells. Cancer Res 38(3): 624-634, 1978.

16 Mori S, Chang JT, Andrechek ER, Matsumura N, Baba T, Yao G, Kim JW, Gatza M, Murphy S and Nevins JR: Anchorageindependent cell growth signature identifies tumors with metastatic potential. Oncogene 28(31): 2796, 2009.

17 Kong L, Schäfer G, Bu H, Zhang Y, Zhang Y and Klocker H: Lamin $\mathrm{a} / \mathrm{c}$ protein is overexpressed in tissue-invading prostate cancer and promotes prostate cancer cell growth, migration and invasion through the PI3K/AKT/PTEN pathway. Carcinogenesis 33(4): 751-759, 2012.

18 Miettinen M, Kovatich AJ and Kärkkäinen P: Keratin subsets in papillary and follicular thyroid lesions. Virchows Archiv 431(6): 407-413, 1997.
19 Wang T-H, Chao A, Tsai C-L, Chang C-L, Chen S-H, Lee Y-S, Chen J-K, Lin Y-J, Chang P-Y and Wang C-J: Stress-induced phosphoprotein 1 as a secreted biomarker for human ovarian cancer promotes cancer cell proliferation. Mol Cell Proteomics 9(9): 1873-1884, 2010.

20 Ciocca DR and Calderwood SK: Heat shock proteins in cancer: Diagnostic, prognostic, predictive, and treatment implications. Cell Stress Chaperones 10(2): 86-103, 2005.

21 Young TW, Mei FC, Rosen DG, Yang G, Li N, Liu J and Cheng $\mathrm{X}$ : Up-regulation of tumor susceptibility gene 101 protein in ovarian carcinomas revealed by proteomics analyses. Mol Cell Proteomics 6(2): 294-304, 2007.

22 Kim KO, Hsu AC, Lee HG, Patel N, Chandhanayingyong C, Hickernell $\mathrm{T}$ and Lee FYI: Proteomic identification of $14-3-3 \varepsilon$ as a linker protein between pERK1/2 inhibition and BIM up-regulation in human osteosarcoma cells. J Orthop Res 32(6): 848-854, 2014.

23 Guo D, Xu Q, Pabla S, Koomen J, Biddinger P, Sharma A, Pabla S, Pacholczyk R, Chang C-C and Friedrich K: Cytokeratin 8 in anaplastic thyroid carcinoma: More than a simple structural cytoskeletal protein. Int J Mol Sci 19(2): 577, 2018.

24 Kirchhoff S, Gupta S and Knowlton A: Cytosolic heat shock protein 60 , apoptosis, and myocardial injury. Circulation 105(24): 2899-2904, 2002.

25 Henne WM, Buchkovich NJ and Emr SD: The ESCRT pathway. Dev Cell 21(1): 77-91, 2011.

$26 \mathrm{Li} \mathrm{L}$ and Cohen SN: Tsg 101: A novel tumor susceptibility gene isolated by controlled homozygous functional knockout of allelic loci in mammalian cells. Cell 85(3): 319-329, 1996.

27 Shao Z, Ji W, Liu A, Qin A, Shen L, Li G, Zhou Y, Hu X, Yu E and Jin G: Tsg101 silencing suppresses hepatocellular carcinoma cell growth by inducing cell cycle arrest and autophagic cell death. Med Sci Monit 21: 3371, 2015.

28 Zhu G, Gilchrist R, Borley N, Chng HW, Morgan M, Marshall JF, Camplejohn RS, Muir GH and Hart IR: Reduction of TSG101 protein has a negative impact on tumor cell growth. Int J Cancer 109(4): 541-547, 2004.

29 Zhang Y, Song M, Cui Z, Li C, Xue X, Yu M, Lu Y, Zhang S, Wang E-H and Wen Y: Down-regulation of TSG101 by small interfering rna inhibits the proliferation of breast cancer cells through the MAPK/ERK signal pathway. Histol Histopathol 26(1): 87, 2011.

$30 \mathrm{Lu} \mathrm{M}$, Marsters S, Ye X, Luis E, Gonzalez L and Ashkenazi A: E-Cadherin couples death receptors to the cytoskeleton to regulate apoptosis. Mol Cell 54(6): 987-998, 2014.

31 Janes SM and Watt FM: Switch from $\alpha v \beta 5$ to $\alpha v \beta 6$ integrin expression protects squamous cell carcinomas from anoikis. J Cell Biol 166(3): 419-431, 2004.

32 Babst M, Odorizzi G, Estepa EJ and Emr SD: Mammalian tumor susceptibility gene 101 (TSG101) and the yeast homologue, VPS23P, both function in late endosomal trafficking. Traffic 1(3): 248-258, 2000.

33 Liu F, Yu Y, Jin Y and Fu S: TSG101, identified by screening a cancer cDNA library and soft-agar assay, promotes cell proliferation in human lung cancer. Mol Biol Rep 37(6): 2829-2838, 2010.

Received July 20, 2018

Revised August 11, 2018

Accepted August 21, 2018 